\title{
Effects of biochar derived from maize stover and rice straw on the early growth of their seedlings
}

\author{
Alie Kamara ${ }^{1}$, Mary Mankutu Mansaray ${ }^{2}$, Abibatu Kamara ${ }^{2}$, Patrick Andrew Sawyerr ${ }^{1}$ \\ ${ }^{1}$ Soil Science Department, School of Agriculture, Njala Campus, Njala University, Sierra Leone \\ ${ }^{2}$ Extension Division, Ministry of Agriculture, Forestry and Food Security, Sierra Leone \\ Email address: \\ aliekamara@njala.edu.sl (Alie K.)
}

\section{To cite this article:}

Alie Kamara, Mary Mankutu Mansaray, Abibatu Kamara, Patrick Andrew Sawyerr. Effects of Biochar Derived from Maize Stover and Rice Straw on the Early Growth of their Seedlings. American Journal of Agriculture and Forestry. Vol. 2, No. 5, 2014 , pp. $232-236$. doi: 10.11648/j.ajaf.20140205.14

\begin{abstract}
Crop residues such as maize and rice are important sources of nutrients and their restitution to the soil is an important residue management strategy for maintaining or improving soil and crop productivity. However, most maize and rice farmers in Sierra Leone burn crop residues during land preparation thereby depriving the soil of this vital resource. An alternative approach is the recycling of crop residues through biochar production. This study was therefore carried out to assess the effects of (i) maize stover biochar on the early growth of maize and (ii) rice straw biochar on the early growth of rice. In this study, biochar $(0 \mathrm{~g}, 12.5 \mathrm{~g}, 25.0 \mathrm{~g}, 37.5 \mathrm{~g}$ and $50.0 \mathrm{~g}$ ) was mixed with $3 \mathrm{~kg}$ of soil (fine sandy loam) and placed in perforated black polythene bags. Maize or rice seeds ( 3 per pot) were planted to $2 \mathrm{~cm}$ depth and later thinned to one plant per pot. All pots were placed in the open under direct sunlight and rainfall. No supplemental irrigation was done since there was sufficient rainfall to supply the required moisture. The experiment was laid in completely randomized design with five treatments and three replications. After four weeks, the experiment was terminated. Mean plant height, stem girth, fresh- and dry-shoot weights of both maize and rice plants generally increased significantly $(\mathrm{p}<0.05)$ relative to the control at biochar applications $\geq 8.3 \mathrm{~g} / \mathrm{kg}$ soil. The results showed that growing maize and rice on soils treated with biochar derived from their residues (maize stover and rice straw respectively) has the potential to improve crop production. Confirmatory field trials and costs/benefits analysis of converting rice and maize residues to biochar will serve as a good guide for policy makers and end-users (farmers) for increased productivity of maize and rice in Sierra Leone.
\end{abstract}

Keywords: Biochar, Rice Straw, Maize Stover, Early Growth, Plant Height

\section{Introduction}

Crop residues are important sources of nutrients and soil organic matter, and their restitution to the soil is an important residue management strategy for maintaining or improving soil and crop productivity. However, most maize and rice farmers in Sierra Leone burn crop residues during land preparation thereby depriving the soil of this vital resource.

Incorporation of maize or rice residues as green manures or compost could offer benefits to maize or rice cropping through the positive effects on soil organic matter, nutrient release, cation exchange capacity, and microbial activity. However, soil organic matter decomposes at a faster rate when incorporated into the soil, particularly on warm humid tropical soils, resulting in rapid loss of soil organic carbon and nutrients through leaching [1, 2]. Rapid decomposition of soil organic matter also leads to the release of biomass carbon in the form of $\mathrm{CO}_{2}$ [3] making the recycling process carbon neutral. An alternative approach is the recycling of crop residues through biochar production.

Addition of biochar to soil helps in improving soil productivity by improving water and nutrient retention [4]. Biochar increases cation exchange capacity of soil $[5,6]$, improves porosity [5] and lowers bulk density thus making root penetration easier. Biochar may also supply some amount of nutrients [7,8] and provide a liming effect to soil [9]. Unlike soil organic matter, biochar does not decompose readily in soils because the biochar carbon is very resistant to microbial attack [10] and as a result it can lasts in the soil for centuries or millennia thereby sequestering carbon in the soil and making the process carbon negative. Thus converting crop residues to biochar 
is an important strategy to improve soil productivity and mitigate global warming through carbon sequestration.

This study was therefore carried out to assess the effects of (i) maize stover biochar on the early growth of maize and (ii) rice straw biochar on the early growth of rice.

\section{Materials and Methods}

\subsection{Description of the Study Area}

The experiment was conducted in Njala Campus, Njala University in Moyamba District in Southern Sierra Leone. Njala is about $255 \mathrm{~km}$ from Freetown, the capital city of Sierra Leone, and is located at an elevation of $128 \mathrm{~m}$ above sea level (altitude), on Latitude $8^{\circ} \mathrm{N}$ and Longitude $12^{\circ} \mathrm{W}$. Njala experiences a tropical climate that is characterized by two main seasons; a rainy season and a dry season. The average annual rainfall is about $2500 \mathrm{~mm}$ and the mean annual temperature ranges from a minimum of $28^{\circ} \mathrm{C}$ to a maximum of $33^{\circ} \mathrm{C}$. The trial was conducted in the rainy season.

\subsection{Biochar Production and Processing}

Maize stover and rice straw were collected from farms in Mosongo, one of the villages around Njala University Campus. Each plant material was thoroughly dried in the sun and converted to biochar using the ELSA stove designed for the BeBi Project in Njala University. [The Elsa stove is a low-tech Top-Lit-Up-Draft (TLUD) bioenergy stove designed for use in domestic cooking and production of biochar for application to soils under the EU-funded project: "Agricultural and Environmental Benefits of Biochar Use in ACP Countries" - 'BeBi']. The charred material (biochar) was quenched with water (by sprinkling water on the hot char) and dried in the sun for a few days. The dry biochar was crushed and sieved through a $2 \mathrm{~mm}$ sieve and stored.

\subsection{Properties of Soil and Biochar}

The soil used in this study had the following characteristics: $\mathrm{pH} 4.7$ (1:1 soil:water ratio), organic carbon $2.1 \mathrm{~g} / \mathrm{kg}$ soil (Walkley-Black), available phosphorus $5.6 \mathrm{mg} / \mathrm{kg}$ soil (Bray \& Kurtz 1), cation exchange capacity $6.2 \mathrm{cmol}(+) / \mathrm{kg}$ soil (neutral $\mathrm{M} \mathrm{NH} \mathrm{NH}_{4} \mathrm{OAc}$ ), exchangeable cations $0.28,0.19,0.12$ and $0.02 \mathrm{cmol}+/ \mathrm{kg}$ soil $\mathrm{Ca}, \mathrm{Mg}, \mathrm{K}$ and $\mathrm{Na}$ respectively, and particle size (70\% sand, $16 \%$ silt and $14 \%$ clay). Maize stover biochar had the following characteristics: $\mathrm{pH}$ 8.4, electrical conductivity (1:5 biochar:water) $3.98 \mathrm{dSm}^{-1}$. Rice straw, on the other hand, had the following characteristics: $\mathrm{pH}$ 8.8, electrical conductivity (1:5) $2.82 \mathrm{dSm}^{-1}$.

\subsection{Experimental Setup}

The experiment consisted of five treatments in three replications in a completely randomized design (Table 1). For each treatment the appropriate amount of biochar was mixed with $3 \mathrm{~kg}$ of soil and placed in perforated black polythene bags. The soil in each pot was moistened with water to saturation level and allowed to drain freely for 48 hours. Maize seeds ( 3 per pot) were planted to $2 \mathrm{~cm}$ depth and then thinned to one plant per pot after emergence. All pots were placed on an elevated platform under direct sunlight and rainfall. No supplemental irrigation was done since there was sufficient rainfall to supply the required moisture.

Table 1. Details of biochar applications rates used in the trial

\begin{tabular}{lll}
\hline Treatment & Biochar Rate (g/3kg soil) & Biochar Rate (g/kg soil) \\
\hline T1 & 0.0 & 0.0 \\
T2 & 12.5 & 4.17 \\
T3 & 25.0 & 8.33 \\
T4 & 37.5 & 12.5 \\
T5 & 50.0 & 16.67 \\
\hline
\end{tabular}

Data was collected every week on plant height and stem girth onto the fourth week when the experiment was terminated. Tiller number was also recorded for rice. At the end of the fourth week, each plant was cut from the base and weighed to determine the weight of the fresh biomass for each treatment. The fresh shoots were dried to constant weight in an oven at a temperature of $75^{\circ} \mathrm{C}$.

\subsection{Data Analysis}

The data was analysed for statistical differences using $\mathrm{LSD}_{0.05}$ and Analysis of Variance (ANOVA) for Completely Randomized Designs (CRD) in the GenStat $12^{\text {th }}$ Edition computer software.

\section{Results}

\subsection{Effect on Plant Height}

Results of weekly plant height measurements for maize and rice (Table 2; also see Figs. 1 and 2)) showed general increases with increasing biochar application levels. However, this increment was not significant $(\mathrm{p}<0.05)$ for maize in weeks one and two, and for rice in weeks one, two and three. In weeks three and four, maize plant height increased significantly $(\mathrm{p}<0.05)$ relative to the control above biochar application level of $4.2 \mathrm{~g} / \mathrm{kg}$ soil. On the other hand, rice plant height increased significantly relative to the control only in week four and beyond biochar application level of $4.2 \mathrm{~g} / \mathrm{kg}$ soil. Generally, further increasing biochar application beyond $4.2 \mathrm{~g} / \mathrm{kg}$ soil did not lead to any significant increase in maize and rice plant heights among biochar treatments. 


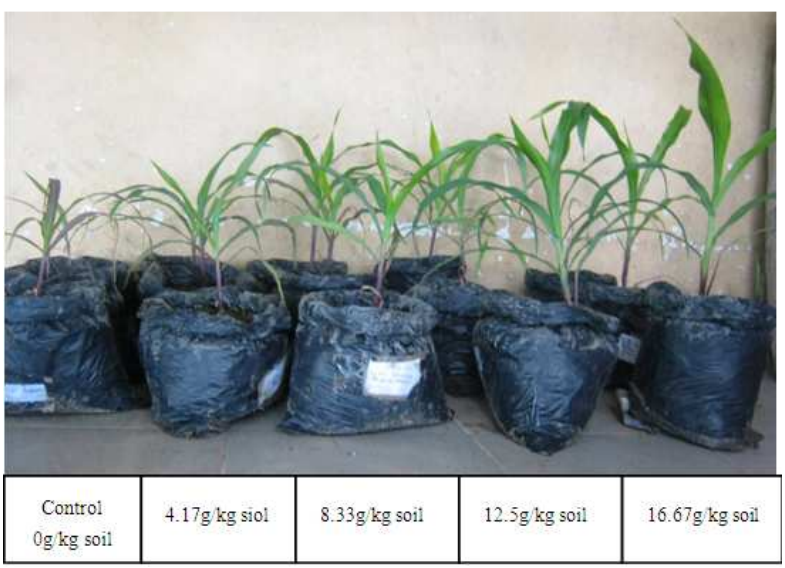

Figure 1. Maize plants after four weeks

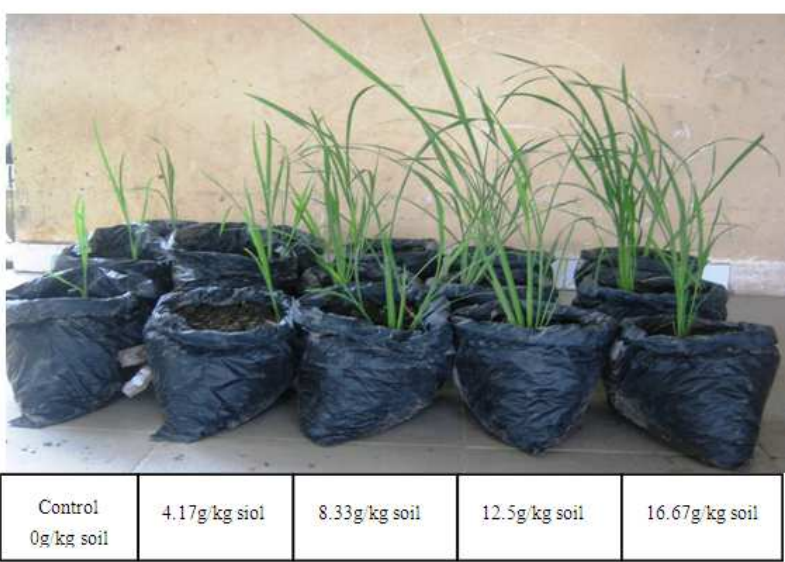

Figure 2. Rice plants after four weeks

Table 2. Mean plant height (cm) of maize and rice seedlings grown on a sandy loam soil treated with increasing levels of maize stover and rice straw biochars respectively

\begin{tabular}{|c|c|c|c|c|c|c|c|c|}
\hline \multirow{2}{*}{$\begin{array}{l}\text { Biochar } \\
\text { (g/kg soil) }\end{array}$} & \multicolumn{4}{|c|}{ Maize Plant Height $(\mathrm{cm})$} & \multicolumn{4}{|c|}{ Rice Plant Height (cm) } \\
\hline & Week1 & Week2 & Week3 & Week 4 & Week1 & Week2 & Week3 & Week 4 \\
\hline 0.0 & $13.43 \mathrm{a}$ & $17.87 \mathrm{a}$ & $15.77 \mathrm{a}$ & $16.60 \mathrm{a}$ & $9.57 \mathrm{a}$ & $14.23 \mathrm{a}$ & $20.03 a$ & $25.00 \mathrm{a}$ \\
\hline 4.2 & $12.50 \mathrm{a}$ & $17.50 \mathrm{a}$ & $20.50 \mathrm{ab}$ & $21.73 \mathrm{ab}$ & $11.50 \mathrm{a}$ & $16.37 \mathrm{a}$ & $18.83 \mathrm{a}$ & $26.80 \mathrm{ab}$ \\
\hline 8.3 & $15.00 \mathrm{a}$ & $20.07 \mathrm{a}$ & $25.33 b c$ & $26.80 \mathrm{bc}$ & $10.83 \mathrm{a}$ & $18.07 \mathrm{a}$ & $24.00 \mathrm{a}$ & $37.20 \mathrm{bc}$ \\
\hline 12.5 & $15.13 \mathrm{a}$ & $21.13 \mathrm{a}$ & $25.87 \mathrm{bc}$ & $27.83 b c$ & $15.33 \mathrm{a}$ & $20.17 \mathrm{a}$ & $27.23 \mathrm{a}$ & $42.33 \mathrm{~cd}$ \\
\hline 16.7 & $16.37 \mathrm{a}$ & $19.80 \mathrm{a}$ & $28.87 \mathrm{c}$ & $31.73 \mathrm{c}$ & $11.63 \mathrm{a}$ & $24.17 \mathrm{a}$ & $27.43 a$ & $42.00 \mathrm{~cd}$ \\
\hline LSD & 3.21 & 5.24 & 6.88 & 6.99 & $5.21 \mathrm{~ns}$ & $10.5 \mathrm{~ns}$ & $8.28 \mathrm{~ns}$ & 11.37 \\
\hline
\end{tabular}

Values with the same letters are not significantly different from each other $(\mathrm{p}<0.05)$

\subsection{Effect on Stem Girth}

Maize and rice (main tiller) stem girths were observed to increase with increasing application levels of biochars derived from their respective residues (Table 3 ). However, except for biochar application level of $16.7 \mathrm{~g} / \mathrm{kg}$ soil in week 2 , the increase in maize stem girth was not significant relative to the control in the first and second weeks. In week 3 a significant difference relative to the control was only observed beyond biochar application level of $4.2 \mathrm{~g} / \mathrm{kg}$ soil whereas in week 4, a significant difference relative to the control was observed for all application levels. Rice showed significant increase in stem girth relative to the control only with biochar application levels of $12.5 \mathrm{~g} / \mathrm{kg}$ soil in week 1 , $12.5 \mathrm{~g} / \mathrm{kg}$ soil and $16.7 \mathrm{~g} / \mathrm{kg}$ soil in week 2 , above $4.2 \mathrm{~g} / \mathrm{kg}$ soil in week 3 and only at $16.7 \mathrm{~g} / \mathrm{kg}$ soil in week 4 . From weeks three and four data, it was generally observed that further biochar applications above $8.3 \mathrm{~g} / \mathrm{kg}$ soil did not increase maize and rice stem girths significantly.

Table 3. Mean stem girth (cm) of maize and rice seedlings grown on a sandy loam soil treated with increasing levels of maize stover and rice straw biochars respectively

\begin{tabular}{|c|c|c|c|c|c|c|c|c|}
\hline \multirow{2}{*}{ Biochar (g/kg soil) } & \multicolumn{4}{|c|}{ Maize Stem Girth (cm) } & \multicolumn{4}{|c|}{ Rice Stem Girth (cm) } \\
\hline & Week1 & Week2 & Week3 & Week 4 & Week1 & Week2 & Week3 & Week 4 \\
\hline 0.0 & $1.10 \mathrm{a}$ & $1.70 \mathrm{a}$ & $1.43 \mathrm{a}$ & $1.60 \mathrm{a}$ & $0.7 \mathrm{a}$ & $0.93 a$ & $1.13 \mathrm{a}$ & $1.57 \mathrm{a}$ \\
\hline 4.2 & $1.27 \mathrm{a}$ & $1.80 \mathrm{a}$ & $1.70 \mathrm{a}$ & $2.03 b$ & $0.7 \mathrm{a}$ & $1.17 \mathrm{ab}$ & $1.4 \mathrm{a}$ & $2.1 \mathrm{ab}$ \\
\hline 8.3 & $1.40 \mathrm{a}$ & $1.87 \mathrm{ab}$ & $2.43 b$ & $2.47 \mathrm{c}$ & $0.83 \mathrm{ab}$ & $1.4 \mathrm{ab}$ & $1.7 \mathrm{~b}$ & $2.37 \mathrm{ab}$ \\
\hline 12.5 & $1.40 \mathrm{a}$ & $1.87 \mathrm{ab}$ & $2.57 \mathrm{~b}$ & $2.87 \mathrm{~cd}$ & $0.9 \mathrm{~b}$ & $1.5 \mathrm{~b}$ & $1.97 \mathrm{bc}$ & $2.6 a b$ \\
\hline 16.7 & $1.43 \mathrm{a}$ & $2.07 \mathrm{~b}$ & $2.67 \mathrm{~b}$ & $3.20 \mathrm{~d}$ & $0.8 \mathrm{ab}$ & $1.73 b$ & $2.29 \mathrm{c}$ & $3.17 \mathrm{~b}$ \\
\hline LSD & $0.43 \mathrm{~ns}$ & $0.27 \mathrm{~ns}$ & 0.49 & 0.43 & $0.16 \mathrm{~ns}$ & 0.48 & 0.44 & 1.23 \\
\hline
\end{tabular}

Values with the same letters are not significantly different from each other $(\mathrm{p}<0.05)$

\subsection{Effect on Shoot Biomass}

The mass of fresh and dry shoot biomass of maize after four weeks of growth are shown in Table 4.1. There was a significant increase in biomass (fresh and dry) relative to the control above biochar application level of $4.2 \mathrm{~g} / \mathrm{kg}$ soil. 
Table 4.1. Fresh and dry shoot biomass of four-week old maize seedlings grown on a fine sandy loam soil treated with increasing levels of maize stover biochar

\begin{tabular}{lll}
\hline $\begin{array}{l}\text { Biochar Rate } \\
\text { (g/kg soil) }\end{array}$ & Fresh Maize Shoot $(\mathbf{g})$ & Dry Maize Shoot $(\mathbf{g})$ \\
\hline 0.0 & $1.09 \mathrm{a}$ & $0.14 \mathrm{a}$ \\
4.2 & $2.69 \mathrm{a}$ & $0.35 \mathrm{a}$ \\
8.33 & $4.15 \mathrm{~b}$ & $0.58 \mathrm{~b}$ \\
12.5 & $5.92 \mathrm{bc}$ & $0.75 \mathrm{~b}$ \\
16.67 & $8.31 \mathrm{c}$ & $1.08 \mathrm{c}$ \\
LSD $(0.05)$ & 2.49 & 0.32 \\
\hline
\end{tabular}

Values with the same letters are not significantly different from each other $(\mathrm{p}<0.05)$

Rice shoot biomass (fresh and dry) as shown in Table 4.2 generally increased with increasing application levels of rice straw biochar. Application of biochar at $4.2 \mathrm{~g} / \mathrm{kg}$ soil did not differ significantly from the control. Rice shoot biomass showed significant difference relative to the control above biochar application level of $4.2 \mathrm{~g} / \mathrm{kg}$ soil for fresh biomass and above $8.33 \mathrm{~g} / \mathrm{kg}$ soil for dry biomass.

Table 4.2. Fresh and dry shoot biomass of four-week old rice seedlings grown on a fine sandy loam soil treated with increasing levels of rice straw biochar

\begin{tabular}{lll}
\hline $\begin{array}{l}\text { Biochar Rate } \\
\text { (g/kg soil) }\end{array}$ & Fresh Rice Shoot $(\mathbf{g})$ & Dry Rice Shoot $(\mathbf{g})$ \\
\hline 0.0 & $0.48 \mathrm{a}$ & $0.14 \mathrm{a}$ \\
4.2 & $0.63 \mathrm{a}$ & $0.20 \mathrm{a}$ \\
8.33 & $2.59 \mathrm{~b}$ & $0.62 \mathrm{ab}$ \\
12.5 & $3.14 \mathrm{bc}$ & $0.78 \mathrm{~b}$ \\
16.67 & $4.11 \mathrm{c}$ & $0.88 \mathrm{~b}$ \\
LSD $(0.05)$ & 1.88 & 0.51 \\
\hline
\end{tabular}

\subsection{Effect on Rice Tiller Number}

Rice started tillering at week 3 for biochar treated pots (Table 5). The control on the other hand only started tillering a week later i.e. at week four. Rice tiller numbers increased with increasing biochar application and differed significantly among all treatments. Thus, application of rice straw biochar resulted in early tillering and increasing application of rice straw biochar generally increased rice tiller numbers.

Table 5. Mean rice tiller numbers produced at three and four weeks after planting on a fine sandy loam soil treated with increasing levels of rice straw biochar.

\begin{tabular}{ccc}
\hline \multirow{2}{*}{$\begin{array}{c}\text { Biochar Rate } \\
(\mathbf{g} / \mathbf{k g} \text { soil) }\end{array}$} & \multicolumn{2}{c}{ Average Tiller Number } \\
\cline { 2 - 3 } 0.0 & Week3 & Week4 \\
4.17 & $0.0 \mathrm{a}$ & $0.7 \mathrm{a}$ \\
8.33 & $1.0 \mathrm{~b}$ & $1.7 \mathrm{~b}$ \\
12.5 & $2.0 \mathrm{c}$ & $3.0 \mathrm{c}$ \\
16.67 & $3.0 \mathrm{~d}$ & $4.0 \mathrm{~d}$ \\
LSD (0.05) & $3.3 \mathrm{e}$ & $5.3 \mathrm{e}$ \\
\hline
\end{tabular}

\section{Discussion}

The overall objective of this study was to demonstrate the usefulness of recycling crop residues through biochar production. The study generally revealed that there is a potential for improving maize and rice production using biochar derived from their residues.

This study has shown that application of biochar derived from maize and rice residues to soil sown to maize and rice respectively could increase crop growth at the early stages (four weeks) relative to the control (where no biochar was applied). Generally, there was an increase in plant growth as measured in terms of plant height, stem girth, and shoot biomass. At the very early stages of growth (one and two weeks) there were no significant differences in plant growth between biochar treatments and the control.

The observed increase in growth for each crop was only significantly different from the control at biochar application levels of $\geq 8.33 \mathrm{~g} / \mathrm{kg}$ soil and above. However, applying biochar above this level did not lead to any further significant increase in maize and rice growth indicating an optimum application level of about $8.33 \mathrm{~g} / \mathrm{kg}$ soil for biochars derived from maize and rice residues.

The relative increase in crop growth at the early growth stages as observed in this study could be attributed to the soil enhancing properties of the rice straw and maize stover biochars, in particular, the observed increase in $\mathrm{pH}$ (from 4.7 to 5.5 by maize stover biochar and to 5.8 by rice straw biochar). Both biochar types had high $\mathrm{pH}$ ( 8.4 for maize biochar and 8.8 for rice straw biochar) and increased soil $\mathrm{pH}$ when applied to soil. Soil $\mathrm{pH}$ is an important property that influences nutrient retention and availability [11]. Some biochar have been reported to increase soil $\mathrm{pH}$ and thus act as liming materials [12,9]. Several studies have also reported $\mathrm{pH}$ increases with biochar application to soil [13, 14]. The increase in soil $\mathrm{pH}$ due to application of rice straw and maize biochars could be used to explain the observed differences between the control and the biochar treatments, particularly when no fertilizer was applied. The soil used in this study was very acidic $(\mathrm{pH} 4.7)$ and could reduce crop growth in the absence of soil amendment such as liming to counteract the effects of acidity. The increase in soil $\mathrm{pH}$ observed in this study may have had positive effects on the growth of maize and rice seedlings.

Application of rice straw biochar was found to increase rice tiller numbers significantly among all treatments. This indicated that biochar had a strong positive effect on rice tiller numbers than other plant growth parameters such as plant height and stem girth as measured in this study.

\section{Conclusion}

The results of this study have demonstrated that recycling crop residues such as rice straw and maize stover through biochar production and application to soil could be a useful residue management strategy for improving rice and maize production on sandy loams of Sierra Leone. 
Generally application of biochar improved maize and rice growth compared to the control where no biochar was applied. However, applications beyond $8.3 \mathrm{~g} / \mathrm{kg}$ soil did not lead to any significant increase in the growth of maize and rice plants. Application of biochar also resulted in early tillering.

\section{Acknowledgements}

The authors would like to thank the field technicians Joseph S. Domingo and Luseni Jaward, and the laboratory technician Samuel Jaia all of the Department of Soil Science Njala University, Sierra Leone for their assistance in soil sample collection and preparation. We will also like to thank Mr Tamba in the agricultural engineering Department for his assistance in biochar production. Special thanks also to Mr J.E. Norman for helping in the statistical analysis of rice data.

\section{References}

[1] H. Tiessen, E. Cuevas, and P. Chacon. The role of soil organic matter in sustaining soil fertility. Nature, 371: 783-785, 1994.

[2] W. Zech, N. Senesi, G. Guggenberger, K. Kaiser, J. Lehmann, T. M. Miano, A. Miltner, G. Schroth. Factors controlling humification and mineralization of soil organic matter in the tropics. Geoderma 79, 117-161, 1997.

[3] P. M. Fearnside. Global warming and tropical land-use change: greenhouse gas emissions from biomass burning, decomposition and soils in forest conversion, shifting cultivation and secondary vegetation. Climatic Change 46:115-158, 2000.

[4] B. Glaser, J. Lehmann, and W. Zech. Ameliorating physical and chemical properties of highly weathered soils in the tropics with charcoal: A review. Biol Fertil Soils., 35, 219-230, 2002.

[5] M. I. Bird, P. L. Ascough, I. M. Young, C. V. Wood, and A. C. Scott. (2008). X-ray microtomographic imaging of charcoal. J. Archaeol. Sci. 35, 2698-2706.
[6] B. Liang, J. Lehmann, D. Kinyangi, J. Grossman, B. O’Neill, J. O. Skjemstad, J. Thies, F. J. Luizao, J. Peterson, and E.G. Neves. Black carbon increases cation exchange capacity in soils. Soil Sci. Soc. Am. J. 70: 1719-1730, 2006.

[7] K. Chan and Z. Xu. Biochar: Nutrient Properties and Their Enhancement. In 'Biochar for Environmental Management: Science and Technology'. (Eds J. Lehmann and S. Joseph) pp.53-66, 2009. (Earthscan: London, UK).

[8] J. W. Gaskin, R. A. Speir, K. Harris, K. C. Das, R. D. Lee, L. A. Morris and D. S. Fisher. Effect of Peanut Hull and Pine Chip Biochar on Soil Nutrients, Corn Nutrient Status, and Yield. Agronomy Journal. 102:623-633, 2010.

[9] L. Van Zwieten, S. Kimber, S. Morris, K. Y. Chan, A. Downie, J. Rust, S. Joseph, and A. Cowie. Effects of biochar from slow pyrolysis of papermill waste on agronomic performance and soil fertility, Plant and Soil 327(1-2): 235-46, 2010.

[10] D. Granatstein, C. Kruger, H. P. Collins, M. Garcia-Perez, and J. Yoder. Use of biochar from the pyrolysis of waste organic material as a soil amendment. Center for Sustaining Agric. Nat. Res. 2009. Washington State University, Wenatchee, WA. WSDA Interagency Agreement. C0800248. (http://www.ecy.wa.gov/pubs/0907062.pdf).

[11] C. Steiner, W. G. Teixeira, J. Lehmann, T. Nehls, J. L. V. de Macedo, W. E. H. Blum, and W. Zech. Long-term effect of manure, charcoal and mineral fertilization on crop production and fertility on highly weathered central amazonian upland soil. Plant Soil, 291, 275-290, 2007.

[12] J. M. Novak, W. J. Busscher, D. L. Laird, M. Ahmedna, D. W. Watts, and M. A. S. Niandou. Impact of biochar amendment on fertility of a southeastern Coastal Plain soil. Soil Science, 174(2), p.105-112, 2009

[13] K. Y. Chan, B. L. Van Zwieten, I. Meszaros, D. Downie, D. and S. Joseph. Using poultry litter biochars as soil amendments. Australian Journal of Soil Research, 46, 437444, 2008.

[14] A. Masulili, W. H. Utomo, and Syekhfani. Rice husk biochar for rice based cropping system in acid soil 1. The characteristics of rice husk biochar and its influence on the properties of acid sulfate soils and rice growth in West Kalimantan, Indonesia. Journal of Agriculture Science, 3, 25-33, 2010. 